\title{
Neoliberalismoari aurre egingo dion Berrikuntza Sozial eraldatzailea
}

\author{
Transformative Social Innovation capable \\ to get over the present neoliberal stage \\ Eusebio Lasa Altuna
}

Universidad del País Vasco/Euskal Herriko Unibertsitatea (UPV/EHU) GEZKI institutuko kidea

\begin{abstract}
Laburpena: Artikulu honetan neoliberalismoari aurre egingo dion Berrikuntza Sozial Eraldatzailearen kontzeptua finkatu nahi da. Berrikuntza Soziala ulertzeko modu asko daudenez artikulu honen helburua Berrikuntza Soziala gizarte-eraldaketaren alde ipintzea izango da. Berrikuntza Sozial Eraldatzailearen kontzeptua aztertzen denean ezinbestekoa ikusten da errotikako iraulketa bat ematea, kapitalismoarekin haustura bat burutzea, izaeran, bitartekoetan eta antolaketa moduan. Horregatik, artikulu honen asmoa da gizarte-eraldaketan oinarritutako Berrikuntza Sozial Eraldatzailearen zimenduak antolatzea neoliberalismoaren gaurko fasea zalantzan jartzeko eta gizarteari bide berriak irekitzen joateko.
\end{abstract}

Hitz gakoak: Berrikuntza Sozial Eraldatzailea, Garapen Eredu Alternatiboa, Ekonomia Sozial eta Solidarioa.

\begin{abstract}
In this article we want to set up the concept of Transformative Social Innovation capable to get over the present neoliberal stage. As there are many different ways to understand Social Innovation the aim of this article is to use Social Innovation for social transformation. When we talk about Transformative Social Innovation it is necessary a radical change, a breakup with capitalist system in nature, means and organization. Therefore, the intention of this article is to establish the rules for Transformative Social Innovation based on social transformation in order to reconsider the present neoliberal stage and, at the same time, open new ways for society.
\end{abstract}

Keywords: Transformative Social Innovation, Alternative Social Model, Social and Solidarity Economy.

Econlit gakoak: A13, B55, F60, L31, O35, P13

* Harremanetan jartzeko/Corresponding author: Eusebio Lasa Altuna. GEZKI institutu. Universidad del País Vasco/Euskal Herriko Unibertsitatea (UPV/EHU) - eusebio.lasa@ehu.eus

Nola aipatu/How to cite: Lasa Altuna, Eusebio (2019). "Neoliberalismoari aurre egingo dion Berrikuntza Sozial eraldatzailea» GizarteEkonomiarenEuskalAldizkaria/RevistaVascadeEconomíaSocial,16,49-67.(https://doi.org/10.1387/reves.21218).

Jasoa: 13 maiatza, 2019; onartua: 27 abuztua, 2019.

ISSN 1698-7446 - elSSN 2444-3107 / (c) 2019 UPV/EHU 


\section{Sarrera}

Artikulu honen helburua Berrikuntza Sozial Eraldatzailearen terminoaren inguruan teorizatzea da, bereziki eredu neoliberalari aurre egiteko tresna eraginkorra bihurtzeko. Gaur egungo gizartea aztertzen badugu konturatzen gara kapitalismoak desberdintasun sozioekonomiko izugarriak sortzen dituela ez bakarrik munduko biztanleriaren artean, baita ere Europar Batasunaren barruan (Duñaiturria, 2007). Krisi hori ez da bakarrik ekonomikoa. Baita ere soziala, kulturala, politikoa, ekologikoa, ideologikoa eta etikoa. Azken finean, zibilizazioaren paradigma bera krisian dago. Mundua ez dago aldaketen garai baten aurrean bakarrik, aro aldaketa sakon baten ataria gurutzatzen ari da (Mendizabal, 2012). Kapitalismoaren garaipen ideologikoak bere krisi sakona ezkutatzen du ez delako gai gizakiaren etorkizunak planteatzen dituen erronkei, arazoei eta zalantzei erantzuteko. Horregatik adierazi daiteke gaur egungo eredu neoliberalak huts egin duela. Hala ere, jauzia ez da egun batetik bestera emango. Sistema kapitalistak gaitasuna dauka erreproduzitzeko egoera honetaz probetxua ateratzen duten klase sozialak eta interes ekonomikoak daudelako (Peck, 2013). Testuinguru honetan, egunetik egunera garrantzitsuagoa da beste gizarte-eredu bat eraikitzea balio eta politika desberdinekin, elkarkidetasunean, ondasunaren banaketan, parte hartze sozialean eta bizi kalitatean oinarrituta. Horregatik, ezinbestekoa da apustu bat egitea beste garapen eredu baten alde, beste gizarte baten alde.

Hala ere, jakitun gara ez dela lan erraza izango neoliberalismoa garaitzea baino bai ezinbestekoa gaur egungo eredu ekonomiko nagusiak dakarren dualizazioa eta injustizia gainditzeko (Klein, 2013). Bide luze eta aldapatsu hori egiteko artikulu honetan garatzen dugun Berrikuntza Sozial Eraldatzailea tresna egokia izan daiteke helburu hori lortzeko. Hala ere artikulu honen helburua izango da Berrikuntza Soziala gizarte-eraldaketaren alde ipintzea. Hain zuzen ere, Berrikuntza Soziala ulertzeko modu asko daude. Autore batzuk pentsatzen dute Berrikuntza Sozialari buruz hitz egiteko nahikoa dela praktika zahar bat egokitzea, ideia bat beste testuinguru batean aplikatzea edo bazterketa sozialari aurre egiteko edozein neurri hartzea. Ez hori bakarrik, Berrikuntza Sozial Eraldatzailea terminoa erabili duten zenbait autore eta proiektuek ere maila mikroko dinamikak eta aldaketak proposatzen dituzte eraldaketaren aldeko teoria sendo bat antolatu gabe. TRANSIT (2018) proiektua horren adibide esanguratsua izan daiteke. Zenbait autoreentzat proiektu horretan erabiltzen den Berrikuntza Sozial Eraldatzailea ez da nahikoa gaur egungo egitura politikoa eta ekonomikoa gainditzeko. Novy-ren (2017) arabera TRANSIT proiektuak ez du Berrikuntza Soziala sistemaren eraldaketaren mesedera jarri. TRANSIT programak aplikatu duen Berrikuntza Soziala, benetako eraldaketa sakona 
bultzatzea baino, gehiago aritu da neoliberalismoaren korronte nagusiaren barruan mikro aldaketak burutzen.

Artikulu honetan Berrikuntza Sozial Eraldatzailearen kontzeptua aztertzen denean ezinbestekoa ikusten da errotikako iraulketa bat ematea, kapitalismoarekin haustura bat burutzea, izaeran, bitartekoetan eta antolaketa moduan. Horregatik, artikulu honen asmoa da gizarte-eraldaketan oinarritutako Berrikuntza Sozial Eraldatzailearen zimenduak antolatzea neoliberalismoaren gaurko fasea zalantzan jartzeko eta gizarteari bide berriak irekitzen joateko.

Helburu hori betetzeko artikulu honek hurrengo egitura dauka: lehenbiziko atalean Berrikuntza Sozialaren kontzeptuaren hastapena azpimarratuko da. Gero guk garatu nahi dugun Berrikuntza Sozialaren kontzeptuari emango zaio garrantzia. Ondoren, artikulu honetan garatzen den Berrikuntza Sozial Eraldatzailearen giltzarri nagusiak aurkeztuko dira. Azkeneko atalean, berriz, zenbait ondorio aterako dira.

\section{Berrikuntza Sozialaren kontzeptuaren hastapenak}

Berrikuntza Soziala gaurkotasuna duen kontzeptua da. Literatura asko idatzi da Berrikuntza Sozialari buruz. Berrikuntza Sozialaren terminoa arrazoi desberdinengatik eta testuinguru desberdinetan plazaratu da. Berrikuntza Sozialaren kontzeptua lehenbizi soziologoek erabili zuten XIX. mendearen amaieran eta Xx. mendearen hasieran (Ayob, Teasdale eta Fagan, 2016), alde batetik, sarean antolatutako gizarteek nola suspertzen zuten berrikuntza teknologikoa azaltzeko (Tarde, 1899) eta, bestetik, berrikuntzen eragin soziala ulertzeko (Hoggan, 1909).

Bestalde, Berrikuntza Sozialaren kontzeptua 60. eta 70. hamarkadan ikasle eta langile mugimenduak erabili zuten Paris, Berlin eta Europa eta Ameriketako hiriburu desberdinetan (Moulaert, MacCallum eta Hillier, 2013). Izendatzaile komun hori beti gorako ekonomia eta gizarte dinamika parte hartzaileak eta kreatzaileak sortuko zituzten ekimen kolektibo eta eraldaketa sozial desberdinak aipatzeko erabili zen (Chambon, David eta Devevey, 1982). Garai horretan ikasle eta langileriaren demokrazia, generoa eta burujabetzari buruzko eztabaida publikoak gaurkotasun handia zuten.

Baita ere, Berrikuntza Sozialaren terminoa erabiliko da kudeaketa lanetan egituren murriztapenak eta giza sinergiak lortzeko prozesuen beharra azpimarratzeko (Drucker,1987). Termino horrekin adierazi nahi zen gizarte batek ipini behar zituen bitartekoak enpresetan eta gobernuetan zegoen burokrazia astuna arintzeko. Garai berriagotan diskurtso hori alde batera utzi da New $\mathrm{Pu}$ blic Management (NPM) metodoen aldeko estiloak eta ereduak bultzatzeko.

Ayob et al.-ek (2016) azterketa bibliometrikoa erabili dute Berrikuntza Sozialaren kontzeptualizazio desberdinak sailkatzeko. Bertatik atera den 
ondorio nagusiena da Berrikuntza Sozialaren literatura sailkatu daitekeela hiru gai nagusien inguruan: berrikuntza teknologikoa, gizarte-harremanak eta gizartean sortutako eraginak kontuan hartuta. 1989tik aurrera argitaratutako argitalpenak sailkatu daitezke gai horien lau konbinaketa desberdinen arabera: gizarte harremanak, gizartean eraginak, gizarte harremanak eta gizartean eraginak, eta gizarte harremanak eta berrikuntza teknologikoak. Gainera, 1999 urtea baino lehen ez dago patroi argi bat Berrikuntza Sozialaren kontzeptua zehazteko garaian. Literatura zientifiko gehiena gizarte harremanen ikuspegi soziologiko batetik dator eta gutxieneko argitalpenak, berriz, berrikuntza teknologikoarekin lotzen dira. 2000. urtera itxaron beharko da Berrikuntza Sozialaren kontzeptuaren atzean gizarte-aldaketak eragingo dituen gizarte harremanen forma berriak azalarazteko. Ordutik aurrera, nahiz eta Berrikuntza Sozialaren azken ikuskera hori gailenduko den, gutxieneko literatura batek jarraituko du aldaketa teknologikoari garrantzia ematen.

Gainera, Ayob et al.-ek (2016) Berrikuntza Sozialaren kontzeptu zabal hori hiru proposamen zehatzetara mugatzen dute. Lehenbiziko proposamenak, literatura soziologikotik eratorrita baina baita ere teknologia eta gizarte aldaketan, zientzia politikoan eta pentsamenduaren diseinuaren literaturan presente dagoena, Berrikuntza Sozialaren kontzeptuak elkarlanerako forma berrien aplikazioa dakar, norbanakoen edo erakundeen artean, eta sarritan gobernuaren, gizarte zibilaren eta hiritarren arteko harremanak berritzea eta horizontalagoak bihurtzea eskatzen du. Bigarren proposamena, teknologia eta aldaketa sozialen literaturatik eta zientzia politikotik datorrena, Berrikuntza Sozial horiek gizarte eta botere harreman berri batetara eraman gaitzake. Azkenik, hirugarren proposamenak, enpresa-administrazioan eta kudeaketa-literaturan agertzen dena, berrikuntzak ikuspegi funtzionaletik gizartean eragin positiboa eduki behar duela defendatzen du, bizi kalitatea eta kantitatea handituz (Pol eta Ville, 2009).

\section{1. taula}

Berrikuntza Sozialaren hiru proposamen zehatz

\begin{tabular}{c|l}
\hline Lehen proposamena & Elkarlanerako forma berrien aplikazioa dakar \\
\hline Bigarren proposamena & Gizarte eta botere harreman berri batera garamatza \\
\hline Hirugarren proposamena & $\begin{array}{l}\text { Enpresa-administrazioan eta kudeaketan garatzen da eta } \\
\text { gizartean eragin positiboa eduki behar du, bizi kalitatea } \\
\text { eta kantitatea handituz }\end{array}$ \\
\hline
\end{tabular}

Iturria: Ayob et al. (2016) ikerketatik ateratako datuekin geuk egina. 


\section{Garatu nahi dugun Berrikuntza Sozialaren kontzeptua}

Berrikuntza Sozialaren ikuspegi eta eskema zabal horren barruan interes berezia jarri dugu erakundeen gobernantzan eta funtzionamendu demokratikoan. Baita ere, gizabanakoen inbertsioen ordainsarietan baino gehiago ongizate kolektiboan zentratu da gure atentzioa. Aldi berean, gure hausnarketari gizarte mugimenduaren ikuspegia txertatu nahi izan diogu momentuko gizarte-arauak auzian jarriz eta gizarte-ordena berria aldarrikatuz. Horregatik artikulu honetan bereziki Quebec-eko eta Europako autoreetan oinarritu gara. Hau da, hurbilketa anglosaxoia alda batera utzi dugu eta bereziki korronte frankofonoko autoreak aukeratu ditugu.

Gainera, Berrikuntza Soziala zehazteko garaian tradizio erradikalean eta normatiboan zimenduak jarri ditugu. Bertan, aldaketa soziala (eta politikoa) gizarte-erlazioen berrikuntzaren ondorio bezala ikusten da. Tradizio erradikala, Berrikuntza Sozial indartsua daramana, koprodukziotik oso gertu dago. Gainera, koprodukzio hori lankidetzan, ideia berrien sorkuntzan, ahalduntzean eta gizartearen eraldaketan sostengatzen da (Bovaird eta Loeffler, 2012; Brandsen eta Pestoff, 2006).

Guk landuko dugun Berrikuntza Sozialaren ikuskera hori asko zabaldu da neoliberalismoaren hazkunde-ereduak sendotasunik erakutsi ez duelako (Klein, 2013). Eredu neoliberalaren krisiak eragile sozialak behartzen ditu arazo sozial nagusiei erantzun bat aurkitzera, hau da, berrikuntza bultzatzera.

Bide hori jarraituz Berrikuntza Sozialera Kleinek (2013) proposatutako hiru ikuspegi desberdinetatik gerturatuko gara. Alde batetik, Ikuspegi epistemologikoa daukagu. Hurbilketa alternatibo honek Berrikuntza Soziala paradigma aldaketa baten parte kontsideratzen du. Ezagupena koeraikuntzaren emaitza da, ikertzaileen eta aktore desberdinen elkarlanerako ahaleginaren emaitza izango da faktore lokalak eta globalak kontuan hartuz. Bestetik, Ikuspegi etikoa garatzen da. Zentzu etikoa kontuan hartzen bada Berrikuntza Sozialak elkarrekin ikasteko bitarteko bat bezala eta pertsona hauskorren bizi baldintzak hobetzeko gaitasunak handitzeko tresna moduan funtzionatzen du. Aldi berean, ikuspegi etikoak ere gizarte-segmentu hori prekarietatean mantentzen duen ingurumen instituzionala eraldatzeko bitartekoak hobetzen ditu. Azkenik, Ikuspegi estrategikoa aztertzen bada Berrikuntza Soziala proiektu integratzaile baten gidaria bihurtzen da ongizatea sortu eta banatzeko Komunitateko aktore politiko, sozial eta ekologikoek osatutako sare bati esker. Horretarako ezinbestekoa da alde batetik, maila globala, nazionala eta lokala batzea eta bestetik, giza jardueraren atal desberdinak koordinatzea, besteak beste, arlo publikoa, soziala eta pribatua. 


\section{1. taula}

Berrikuntza Sozialera gerturatzeko hiru ikuspegi

\begin{tabular}{|c|c|c|}
\hline Epistemologikoa & Etikoa & Estrategikoa \\
\hline $\begin{array}{l}\text { Berrikuntza Soziala: para- } \\
\text { digma aldaketa baten on- } \\
\text { dorioa. }\end{array}$ & $\begin{array}{l}\text { Berrikuntza Soziala: } \\
\text { 1. Elkarrekin ikasteko bi- } \\
\text { tarteko bat. }\end{array}$ & $\begin{array}{l}\text { Berrikuntza Soziala: } \\
\text { proiektu integratzaile baten } \\
\text { gidaria. }\end{array}$ \\
\hline $\begin{array}{l}\text { - Ezagupena ikertzaileen } \\
\text { eta aktore desberdinen } \\
\text { elkarlanerako ahalegina- } \\
\text { ren emaitza da: Koerai- } \\
\text { kuntzaren ondorioa. } \\
\text { — Faktore lokalak eta glo- } \\
\text { balak Kontuan hartu } \\
\text { beharko dira. }\end{array}$ & $\begin{array}{l}\text { 2. Pertsona hauskorren } \\
\text { bizi baldintzak hobe- } \\
\text { tzeko gaitasunak han- } \\
\text { ditzeko tresna. } \\
\text { _ Prekarietatea sor- } \\
\text { tzen duen Inguru- } \\
\text { men instituzionala } \\
\text { eraldatzeko bitarte- } \\
\text { koak hobetzen ditu. }\end{array}$ & $\begin{array}{l}\text { - Maila globala, nazionala } \\
\text { eta lokala batu behar da. } \\
\text { — Giza jardueraren atal } \\
\text { desberdinak (arlo publi- } \\
\text { koa, soziala eta pribatua) } \\
\text { koordinatzea eskatzen } \\
\text { du. }\end{array}$ \\
\hline
\end{tabular}

Iturria: Kleinen (2015) datuekin geuk egina.

Aldi berean, 80. hamarkadatik aurrera garatu diren aldaketa sozialaren kontzepzio estuak eta deterministak zalantzan jarriko ditugu (Hillenkamp, 2016). Garai horretan Hirugarren Mundua bezala ezagutzen zen eremuko kanpo-zorren krisiaren ondorioz berriztatze ekonomikoko estatu-politikak zaharkituta gelditzen dira eta, aldi berean, Brundtland (1987) txostenak krisi ekologikoaren eskala handiko kontzientzia hartzera laguntzen du. Doktrina neoliberalaren aurkako jarrerak alde batetik gizarte zibilaren indarketa dakar eta bestetik aldaketaren motor bezala norbanakoen eta Garapenerako Gobernuz Kanpoko Erakundeen papera sendotuta ateratzen da.

Ikuspegi horri Bouchard-ek (2013) garatu duen Berrikuntza Sozialaren prozesuen eta produktuen izaera kolektiboa gehituko diogu. Gerturatze horretan, nahiz eta mikrosistemak uniformetasun sozial berriekin esperimentatzeko eremuak badiren ere, berrikuntza ez da ekimen arrazional eta borondatezko batetik bakarrik sortzen. Kasu honetan Berrikuntza Soziala egiturazko geldialdiak gizarte-mugimenduen ekimenekin lotuz garatzen da. Krisi garaietan, arau makro-sozialek (merkatua, estatua, negoziazio kolektiboa) astindu ederra jasotzen dute toki gehiago eginez berrikuntzarako eta esperimentaziorako. Lidergoa duten eragile sozialengatik eta tokian tokiko esperimentuetatik sortutako erregulazio berriak gero gizarte osora zabalduko dira.

Hurbilketa honetan Berrikuntza Sozialaren definizio zabalduenetakoa Quebeceko CRISES (Centre de Recherche sur les Innovations Sociales) 
erakundearena da: «Berrikuntza Soziala eragile sozialek martxan ipini duten esku-hartze bat da helburu bati erantzuteko, behar zehatzak betetzeko, irtenbide bat eskaintzeko edo aukera batez baliatu ekimenerako giza harremanak aldatzeko, ekintzarako esparrua eraldatzeko edo kultura-norabide berriak proposatzeko» (Bouchard, 2013). CRISESen definizio hori hobeto ulertzen da esanez Berrikuntza Soziala behar zehatzei emandako erantzun bat dela baino baita ere Berrikuntza Sozialak aldaketa soziala bultzatzen duela ikuspegi berri baten bitartez arazoak ikusi eta definitzeko eta bidez batez arazo horiei irtenbideak aurkitzeko (Lévesque, 2006).

Berrikuntza Sozialaren definizio horri Moulaert et al.-eren (2013) hausnarketa gehituko diogu. Azken autore horiek azpimarratzen dute Berrikuntza Sozialari buruz hitz egiten dutenean irtenbide aurrerakoiak bilatzen ari direla besteak beste bazterketa, eskasia, alienazioa eta ongizate faltari aurre egiteko. Hau da, aurrerapen soziala eta garapena bultzatzeko tresna bezala identifikatzen dute. Horregatik, Moulaert et al.-entzat (2013) Berrikuntza Sozialaren eginkizun nagusi bat bazterketa eta behar egoerei era egokian erantzuteko ekimen kolektibo eta eraldaketa sozial mota desberdinak definitzea da. Berrikuntza Sozialarekin anbizio politiko-ideologikoa martxan ipini nahi da teoria horiek aplikatuz eta garapen politiketan nagusi izan diren teknologian eta negozioan oinarritutako diskurtsoei alternatiba bat eskainiz. Hain zuzen ere, Moulaert et al.-ek (2013) Berrikuntza Soziala ikuspegi epistemologiko batetik aztertzen dute arlo politiko eta sozialari garrantzia emanez eta garapen alternatiborako estrategia bateko osagai nagusi bat bezala aldarrikatuz. Berrikuntza Soziala aurkezten dute askotariko disziplinen arteko ikerketaren ardatz eragile moduan eta aldi berean jarduera kolektiboaren gidari.

Aldi berean, Bouchard (2007) eta Richez-Battesti, Petrella eta Valladeri (2012) jarraituz, ekonomia sozial eta solidarioa Berrikuntza Sozial horren motorra bihurtuko da. Alde batetik, Berrikuntza Sozialaren ikuspegi funtzionalagoa hartzen badugu, ekonomia soziala saiatzen da estatuak edo merkatuak betetzen ez dituen beharrak estaltzen. Bestetik, Berrikuntza Sozialaren ikuspegi eraldatzaileagoa aplikatzen badugu, ekonomia sozialak borroka sozialekin batera behar ekonomiko eta sozialei erantzuteko modu berriak asmatuko ditu, tokian tokiko arauak eta instituzioak goitik behera irauliz. Ekonomia sozialak Berrikuntza Sozial iraunkorrak eragiten ditu, antolaketa maila gainditu eta esparru instituzionala ukitu ondoren gaur egungo eredu ekonomikoari alternatiba bat bilatzen dio (Bouchard, 2006).

Horrekin batera, Berrikuntza Sozialaren oinarri honi, ikuspegi instituzionalagoa garatzen duten ekarpenak erantsiko dizkiogu. Hau da, alde batetik, gizartea eraldatzeko praktika berriak, arauak eta erregelak azpimarratuko dira. Eta bestetik, testuinguru instituzionalari eta lokalari garrantzia emango zaio. Ikuspegi horrek atentzio berezia jarriko du lurraldean sor- 
tuko diren prozesu kolektiboetan asegabeko behar sozialak betetzeko, beti ere, gizartea eraldatzeko dinamika baten barruan.

Gainera, Berrikuntza Sozialaren bitartez eraiki nahi den eredu berri hori koherentea izan behar da globalizazioak ekarri dituen sozietate konfigurazio berriekin baina aldi berean hiritarrei eman behar die aitorpena eta ahalmen erreala beren eskubideak eta ardurak gauzatzeko (Lévesque, 2011). Zalantzarik gabe, gaur egungo globalizazio prozesua ikus daiteke batera bizitzeko dinamika inklusibo, solidario eta ekologiko baten aldeko aukera historiko bat bezala. Ikuspegi hori guztiz txertatuta dago hiritarren mugimenduen aldarrikapenekin (Klein eta Harrisson, 2010). Ekimen kolektibo berri horiek erabiliz sortuko dira berrikuntza sozialak han eta hemen, gobernamendu arloan, finantzetan, ingurumenaren babesaren atalean, pobreziaren kontrako borrokan, kulturan, gizarteratze politiketan, ea. (Klein et al., 2010).

Berrikuntza horiek estrategia politiko, ekonomiko, sozial eta ekologiko global baten erreferenteak bihurtu behar dira eta eragina eduki beharko dute Estatuan, kapital pribatuan eta gizarte zibileko aktoreetan ez bada nahi eredu kapitalistak berrikuntza horiek erabiltzea bere makinariaren eraginkortasuna handitzeko (Peck, 2013). Hain zuzen ere, Berrikuntza Soziala eraldaketa soziala bilatzen duten mugimendu sozial eta politikoentzat erreferentzia-puntu garrantzitsua bihurtzen ari da. Baino bestetik, Berrikuntza Soziala erabiltzen ari da kapitalismoaren hurbilketa berri bat bultzatzeko, hots, ongizate-estatuaren krisiaren testuinguruan ekonomia sozial «merkearen» bitartez lanpostu berriak sortzeko eta zerbitzuak pribatizatzeko.

\section{Berrikuntza Soziala «eraldatzailea» izan behar du}

Artikulu honetan egin ditugun hausnarketak ikusita ondorioztatu dezakegu gaur egun erronka bat dela Berrikuntza Soziala gizarte-eraldaketa proiektu baten alde ipintzea. Hain zuzen ere, Berrikuntza Soziala ulertzeko modu asko daudela ikusi dugu. Autore batzuk pentsatzen dute berrikuntzari buruz hitz egiteko nahikoa dela praktika zahar bat egokitzea, ideia bat beste testuinguru batean aplikatzea edo bazterketa sozialari aurre egiteko edozein neurri hartzea. Beste batzuk, berriz, ezinbestekoa ikusten dute errotikako iraulketa bat ematea, haustura bat burutzea, izaeran, bitartekoetan eta antolaketa moduan. Horregatik, argi gelditu da Berrikuntza Sozialaren hitzarekin nahasketa handia sortzen dela Berrikuntza Sozial mota guzti horiek esanahi berdin baten azpian biltzen direlako eta bide batez eraldaketa sozial erreal baten aldeko Berrikuntza Sozialak zurrunbilo horren barruan galduta eta urardotuta agertzeko arriskua dagoelako. Hori dela eta artikulu honen 2. atalean gure asmoa izan da guk garatu nahi du- 
gun Berrikuntza Sozialaren kontzeptuaren oinarriak ondo finkatuta uztea benetako eraldaketaren bidea marrazteko.

Bestalde, azpimarratu nahi dugu ere Berrikuntza Sozial Eraldatzailea terminoa erabili duten zenbait autore eta proiektuek tamaina txikiko aldakuntzak planteatu dituztela eraldaketaren aldeko teoria osatu bat antolatu gabe. TRANSIT (2018) proiektua horren adibide esanguratsua izan daiteke. Egitasmo hori esplizituki Berrikuntza Sozial Eraldatzailearen teoria aztertzeko jaio ondoren bere asmoa aldaketa sakonak burutzea zen. Ikerketaren diseinuan TRANSIT-ek (2018) hiru makro-dinamika ukitu ditu: krisi ekonomikoa, aldaketa klimatikoa eta Informazio eta Komunikazio Teknologien (IKT) iraultza. Hiru makro-dinamika horiek forma hartuko dute ekimen berritzaileen bitartez. Maila desberdineko ikuspegia kontuan hartuz gero, proiektu horren ikerketa taldearen arabera Berrikuntza Sozialak praktika berriak maila mikroan egiteari garrantzia emango dio eta gainera aldaketa sakonagoak eragingo ditu berrikuntza, inflexio-puntu, aldaketa-kontakizun eta gizarte-eraldaketaren bitartez. Aldaketarako eta berrikuntzarako lau bide horiek batera garatzen badira aldaketa sozio-ekonomiko zabalagoa ekarriko du. Hala eta guztiz ere, behetik gorako ekimenen eta merkatu-ekonomia kapitalistaren egituraren arteko lotura oinarrizko lanketa xinple baten bitartez egiten da. Krisiaren fenomenoa deskribatzen denean ez da eraldaketarako teoria bat eraikitzen eta gainera hori ez da kausa-mekanismoekin lotzen.

TRANSIT proiektuak lau urteko ibilbidea eduki du, 2014ko urtarriletik 2017ko abendura arte. Europako Batzordeak aldi berean finantzatu du. Proiektuaren helburua Berrikuntza Sozial Eraldatzailearen teoria bat finkatzea izan da gizartearen ahalduntzea eta aldaketa burutzeko. TRANSIT proiektuak erabili duen ikerketa metodoak enpresari, berritzaile, legegile eta akademikoen arteko berrelikadura sustatu du. Proiektu horretan Europa eta Latinoamerikako nazioarteko 20 sareetan konektatuta dauden berrikuntza sozialak aztertu dira. Hala ere zenbait autoreentzat proiektu horretan erabiltzen den Berrikuntza Sozial Eraldatzailea ez da nahikoa gaur egungo egitura politikoa eta ekonomikoa gainditzeko.

Novy-ren (2017) arabera TRANSIT proiektuak ez du Berrikuntza Soziala jarri sistemaren eraldaketaren mesedera. TRANSIT programak aplikatu duen Berrikuntza Soziala gehiago aritu da neoliberalismoaren korronte nagusiaren barruan mikro aldaketak burutzen benetako eraldaketa sakona bultzatu gabe. Novy-k (2017) berak ere bere Berrikuntza Sozial Eraldatzaile propioa lantzen du. Berarentzat Berrikuntza Sozial Eraldatzailea errealitatea bihurtze eta azaleratzearen prozesu iraunkorra bezala nabaritzen duen ontologian oinarritzen da. Novy-rentzat (2017) Berrikuntza Sozial Eraldatzaileak errealismo kritikoa, transdisziplinaritatea eta pentsamendu utopikoa behar du. Eraldaketa ez da itxura aldaketa txiki bat, 
forma aldaketa sakon bat baizik. Eraldaketa horiek hobeto ulertzeko prozesuetan oinarritutako filosofiaren zientzia behar da. Hau da, errealitatea, natura eta gizartea aztertzeko prozeduran oinarritutako ulermena garatzea eskatzen du. Eraldaketa kolektibo kontzienteak forma sozialak ikastea esan nahi du erakundeak, diskurtsoak eta bizitzeko moduak aldatzeko.

Frank Moulaerten ikerketa tradizioak ere beti azpimarratu izan ditu Berrikuntza Sozialaren ahalduntze eta eraldaketa dimentsioak (Moulaert, MacCallum, Mehmood eta Hamdouch, 2013). Moulaertek argudiatzen du Berrikuntza Soziala praktika bat dela giza-zintzotasuna zentzu zabalean hobetzeko, garapen eta hazkunde materialistatik haratago joanez. Gainera, nabarmentzen du Berrikuntza Sozial horren helburu nagusiak, besteak beste, erakundeak eraldatzea, botere-egitura zapaltzaileak kentzea, bete gabeko beharrak lortzeko ekimen kolektiboak burutzea eta behetik gorako giza-erlazioen ahalduntzea direla. Ondorioz, edozein ikerketan teoria praktikarekin lotu behar da ekintza eta hausnarketa elkarlotuta doazelako.

Ungerrek (2015) ere Berrikuntza erradikalaren bidea aipatzen du. Autore horrek Berrikuntza Sozial minimalista eta Berrikuntza Sozial maximalistaren kontzeptuak erabiltzen ditu. Berrikuntza Sozial minimalistak aurpegi gizatiarra jartzen dio bestela jasangaitza izango zen egoera bateri. Aldiz, Berrikuntza Sozial maximalistak aldaketa sakonak aldarrikatzen ditu. Ungerrek (2015) esperimentatzeko metodo berri bat eskaintzen du. Metodo horrek aldaketa lortzen du gizarte-ingeniaritza sozialdemokratatik aldenduz. Gerra ondorengo kapitalismoaren ongizate sozialdemokratarekin gizarte politika eraginkorra izan da. Eredu hori zentralista, burokratikoa eta homogeneizatzailea kontsidera daiteke. Urteak joan ahala gizarte-ingeniaritza sozialdemokrata hori desegiten eta ospea galtzen joan ondoren eraldaketarako metodo aurrerakoi bat aurkitzeko premiazko behar bat sortzen da. Eraldaketarako metodo horrek beste mundu baten aldeko pentsamendu ameslaria gaur egungo errealitate pragmatikoarekin lotuko du. Ungerrek (2015) proposatzen duen esperimentazioak egitasmo bikoitza dauka, erradikala eta erreformista. Eskala txiki eta epe luzeko eraldaketen arteko dialektika hori egoki garatzeko berrikuntza sozial maximalistak behar dira, zatika eta graduala metodoetan baina bestalde erradikala asmoetan.

Hala ere, Berrikuntza Sozial Eraldatzailearen hurbiltze desberdinak aurkeztu ondoren gure artikulu honetan urrutiago joan nahi da. Berrikuntza Sozialari «Eraldatzailea» terminoa gehitzen zaio kapitalismoari aurre egingo dion beste eredu alternatibo bat eraikitzeko tresna egokia izan nahi duelako. Hain zuzen ere, Berrikuntza Sozial Eraldatzaileak esanahi politiko-ideologiko sendoa eduki nahi du. Bereziki, giza garapena bilatzen duten mugimendu sozial eta politikoentzat gida indartsua bihurtzeko.

Guretzat Berrikuntza Sozial Eraldatzailearekin apustua eta nahia beste garapen eredu alternatibo bat eraikitzea da. Hau da, beste eredu ekono- 
miko alternatiboaren bidean Berrikuntza Sozial Eraldatzailearen kontzeptua mahai-gaineratu nahi da. Horretarako garrantzitsua da Berrikuntza Sozial Eraldatzailearen rola ondo finkatzea eta diskurtso sozio-politiko alternatiboak eraikitzea aldaketa sozialaren aldeko potentzialtasuna garatzeko. Lehiakortasunaren tesiaren aurrean Berrikuntza Sozial Eraldatzaileak antitesi bat eskaini behar du eta, era berean, elkartasunezko kontra-ideologia iradokitzen du. Aldi berean, Berrikuntza Sozial Eraldatzaileak mobilizatzeko berezko joerarekin batera kapitalismoak eragindako bazterketa, alienazioa eta baliabideen eskasiaren aurka agertzen da. Sarritan zapaltzailea den egitura instituzional nagusiaren kontra erreakzionatzea Berrikuntza Sozial Eraldatzailearen eginkizun garrantzitsua izan beharko luke. Hain zuzen ere, artikulu honetan bultzatzen den Berrikuntza Sozial Eraldatzailea definitzeko eta zehazteko hiru aldagaien arabera egituratu da proposamena:

1. Berrikuntzaren izaera. Berrikuntzaren izaera kontuan hartzen bada Berrikuntza Sozial Eraldatzailea gizartearen eraldaketara bideratuko da. Horrek esan nahi du bere helburua gizarte eredu berri bat eraikitzeko prozesu eraldatzaileak martxan ipintzea dela. Gainera, xede hori lortzeko kontzeptuak, teoriak, praktikak eta estrategiak elkarlotuko dira.

Prozesu eraldatzaile horiek neoliberalismoak azken hamarkadetan garatu duen ingurumenetik abiatuko dira. Hain zuzen ere, jokaleku neoliberala mugimenduan dagoen esparru bat izanik aukera sortzaileak egon daitezke. Ez hori bakarrik, espazio sozial alternatiboak sortu nahi dira balore indibidualista, kontsumista eta atzerakoiekin funtzionatzen duten sare eta guneei aurre egiteko. Elkarren arteko elkarrizketa sendotuko da eta proposamen desberdinak erkatuko dira gehiengoaren helburuak batzen dituenak eraikitzen joateko.

Gero espazio ekonomiko, sozial eta politiko alternatibo horiek erreferentzia puntuak bihurtzea da helburua. Arnasgune horiek prozesu eraldatzailearen zabaltze estrategian paper garrantzitsua joka dezakete. Esperientzia positibo eta eraldatzaile horiek ezagunak egiten diren heinean beste espazio batzuetara garraiatuko dira.

Tokian tokiko proposamenak nazioarteko dinamikekin lotuko dira. Bertako esperientzia emankorrak nazioarteko sare alternatiboetara bideratuko dira. Horrekin batera, informazio-trukaketa indartu, jarduera-ildoak burutu eta koordinazio-dinamikak martxan ipiniko dira.

Berrikuntza Sozial Eraldatzailea garatzeko ezinbestekoa da balioen dimentsioari garrantzia ematea. Aldaketa soziala bultzatzeko baliodun pertsonak ezinbestekoak dira. Hain zuzen ere, Berrikuntza So- 
zial Eraldatzailearen azpian dauden balioek korronte nagusiko balioen aurrez aurre egon beharko dute. Aldaketa sozial aurrerakoia lortzeko, besteak beste, irabazi asmorik gabeko jarduera ekonomikoan oinarritutako eredu alternatiboak, pertsonen autogestioa, zuzeneko inplikazioa erabakitzeko ahalmen-prozesuetan, justizia sozialaren bilaketa, aukera berdintasuna eta genero parekidetasuna bultzatu beharko dira.

Bestalde, prozesu eraldatzaileak martxan ipintzeko gatazkaren dimentsioa txertatzea ere garrantzitsua da. Kasu askotan gatazka sortzea ezinbestekoa da, urratsak emateko, konponketak bilatzeko eta desoreka sozial, ekonomiko eta ekologikoak gainditzeko. Bidegabekeria bat gertatzen denean, giza eskubideak errespetatzen ez direnean, zapalkuntza egoera bat ematen denean gatazka pizten bada horrek atentzioa sortzen du eta arazo horretan inplikatuta dauden aktore desberdinak ardurapean ipintzen ditu mekanismo desberdinen bitartez irtenbide zentzuzkoak eta sortzaileak lortzeko. Zentzu horretan gatazka gizarte eraldaketaren iturri da eta, gainera, eraginkorra izan daiteke kapitalismoak eragindako desorekak eta bidegabekeriak salatzeko eta, bide batez, proposamen alternatibo egingarriak inplementatu arazteko.

2. Berrikuntzaren dimentsio soziala. Berrikuntza Sozial Eraldatzailearen azken helburua ez da bete gabeko edo gaizki betetako behar sozialei aurre egitea. Ez eta ere esku hartze sozialari buruz bakarrik aritzea. Gizartearen eraldaketa integralaren dimentsioari heldu nahi dio. Xedea beste garapen eredu alternatibo bat eraikitzea da planetaren etorkizuna bermatzeko, lurraren bioaniztasun ekologikoa, kulturala eta linguistikoa sostengatzeko eta mundu parekidea, justu, bidezkoa eta solidarioa eraikitzeko. Horregatik, Berrikuntza Sozial Eraldatzaileak arlo ekonomikoa, soziala, kulturala, politikoa, ekologikoa, ideologikoa eta etikoa landuko ditu eta genero berdintasuna helburu bezala jarriko du.

Berrikuntza Sozial Eraldatzaileak premia materialak baino zerbait gehiago asetu nahi ditu. Pertsona protagonista izango den gizartearen eraikuntzan inbertitu nahi du. Indar guztiak gizarteko premia indibidual eta kolektiboak asetzeko antolatuko dira. Hau da, ekonomia pertsona eta kolektibitatearen zerbitzura jarriko da eta ez alderantziz. Berrikuntza Sozial Eraldatzaileak estatuaren esku hartzea gizartearen gehiengoaren alde burutuko du. Hau da, antolaketa instituzional konprometitua izan behar du, lankidetza-gobernantzan oinarrituz, sektore behartsuei lehentasuna emanez, hiritar guztiei gizarte zerbitzuak eta segurtasuna eskainiz, hiritar ororentzat oinarrizko eskubide sozialak bermatuz, ondasunaren banaketa gauzatuz, zer- 
bitzu publiko egokiak bermatuz eta gizarte eta ekonomia alorreko desberdintasunak gaindituz.

Berrikuntza Sozial Eraldatzaileak merkatuaren paper positiboa bultzatuko du, beti ere sektore herrikoi zabalen alde arituz. Kontuan hartu behar da merkatuak paper bikoitza jokatu dezakela. Desberdindu egin beharko da klase herrikoien interesen alde aritzen den merkatua merkatu inperfektu txar batetik. Hau da, Berrikuntza Sozial Eraldatzaileak merkatu eraginkorra sustatuko du, gizartearen interes indibidual eta kolektiboekin bat eginez eta enpresa-ahaleginak eta ekimen pribatuak kolektiboaren mesedera bideratuz.

Gainera, Berrikuntza Sozial Eraldatzaileak Ekonomia Sozial Eraldatzailearen ahalmen guztia askatuko du. Kontuan hartu behar da Ekonomia Sozial Eraldatzailea Berrikuntza Sozial Eraldatzailearen tresna estrategikoa dela, harrobia eta sustatzailea. Prozesu eraldatzaileak martxan ipintzeko euskarrietako bat baita ere.

3. Berrikuntzaren antolaketa. Prozesu eraldatzailea antolatu egin behar da neoliberalismoaren aurrean beste eredu transformatzaile sendo eta posible bat eraikitzeko. Helburu hori lortzeko elkartasuna, integrazioa eta elkarlana bultzatuko da indibidualismoa, sektorializazioa eta zatiketa alboratuz.

Gainera, estrategia egokia antolatzeko aztertu behar da zein den gaur egungo sistema neoliberalaren eta Berrikuntza Sozial Eraldatzailearen dinamiken arteko dialektika. Baita ere, komeni da ikertzea eta aurreikustea zeintzuk diren gaur egungo sistema ekonomikoaren dinamika baztertzaileak eta atzerakoiak Berrikuntza Sozial Eraldatzaileak kontra erreakzionatzeko. Kontuan hartu behar da ere zein ekimenek hobetzen duten gizartearen balioak, zein mugimendu sozial edo politiko diren garrantzitsuak aldaketa sozialerako eta zeintzuk diren dinamika sozio-politiko eta instituzional egokiak Berrikuntza Sozial Eraldatzailea tokiko komunitateetan eta enpresetan garaile ateratzeko.

Hiritarren auto-eraketarekin batera eraldaketaren aldeko indar sozial, sindikal, politiko eta instituzionalak bat egingo dute. Antolaketa hori herri eta auzoetan gauzatuko da tokiko arazoak konpontzeko, baina baita herrialdean, nazioan eta nazioartean ere. Elkarren arteko elkarrizketa, koordinaketa eta lan amankomuna sustatuko da urratsez urrats aurrerapenak lortzeko. Hain zuzen ere, epe motzeko pausoak epe erdiko eta epe luzeko pausoekin lotuz. Egin beharreko bidea eta tokian tokiko testuingurua kontuan hartu behar dira estrategia egokia plazaratzeko. Proposamen teorikoak ere praktikarekin uztartzea komeni da egungo errealitatetik abiatuz. Beti ere, korronte neoliberalak asimilatu gabe. 


\section{1. taula}

Berrikuntza Sozial Eraldatzailearen giltzarri nagusiak

\begin{tabular}{|c|c|c|}
\hline $\begin{array}{c}(1) \\
\text { Berrikuntzaren } \\
\text { izaera }\end{array}$ & $\begin{array}{c}(2) \\
\text { Berrikuntzaren di } \\
\text { soziala }\end{array}$ & $\begin{array}{l}\text { (3) } \\
\text { errikuntzaren } \\
\text { antolaketa }\end{array}$ \\
\hline $\begin{array}{l}\text { KA P I T A L I S M O A R I } \\
\text { AURRE EGINGO DION } \\
\text { EREDU ALTERNATI- } \\
\text { BOA ERAIKI } \\
\text { - Prozesu eraldatzaileak } \\
\text { martxan ipini: } \\
\text { - errotikako eraldake- } \\
\text { tak korronte neolibe- } \\
\text { ralak asimilatu gabe. } \\
\text { - kontzeptuak, teoriak, } \\
\text { praktikak eta estrate- } \\
\text { giak elkarlotu. } \\
\text { - neoliberalismoak ga- } \\
\text { ratu duen ingurume- } \\
\text { netik abiatu. } \\
\text { - espazio sozial alterna- } \\
\text { tiboak sortu sare eta } \\
\text { gune neoliberalei au- } \\
\text { rre egiteko. } \\
\text { - espazio ekonomiko, } \\
\text { sozial eta politiko al- } \\
\text { ternatibo horiek erre- } \\
\text { ferentzi puntuak } \\
\text { bihurtu. } \\
\text { arnasgune horiek eza- } \\
\text { gunak egiten diren } \\
\text { heinean beste espazio } \\
\text { batzuetara garraiatu. } \\
\text { - tokian tokiko propo- } \\
\text { samenak nazioarteko } \\
\text { dinamikekin lotu. } \\
\text { Informazio trukaketa } \\
\text { indartu eta jarduera } \\
\text { ildoak burutu. }\end{array}$ & $\begin{array}{l}\text { - Azken helburua ez da } \\
\text { bete gabeko edo gaizki } \\
\text { betetako behar sozialei } \\
\text { aurre egitea. } \\
\text { — Ez eta ere esku hartze } \\
\text { sozialari buruz bakarrik } \\
\text { aritzea. } \\
\text { - Gizartearen eraldaketa } \\
\text { integralaren dimen- } \\
\text { tsioari heldu: } \\
\text { - garapen eredu alter- } \\
\text { natiboa eraiki. } \\
\text { - arlo ekonomikoa, } \\
\text { soziala, kulturala, } \\
\text { politikoa, ekologi- } \\
\text { koa, ideologikoa eta } \\
\text { etikoa landu eta ge- } \\
\text { nero berdintasuna } \\
\text { helburu. } \\
\text { - pertsona eta kolekti- } \\
\text { bitatea protagonista } \\
\text { izango den gizartea- } \\
\text { ren eraikuntzan in- } \\
\text { bertitu. } \\
\text { - Estatuaren esku har- } \\
\text { tz e a gi zart e a r en } \\
\text { gehiengoaren alde bu- } \\
\text { rutu: } \\
\text { - antolaketa institu- } \\
\text { zional konprometi- } \\
\text { tua. } \\
\text { - Lankidetza-gober- } \\
\text { nantza ezarri. } \\
\text { sektore behartsuei } \\
\text { lehentasuna eman. }\end{array}$ & $\begin{array}{l}\text { - } \text { gaur egungo eredu } \\
\text { neoliberalaren eta Be- } \\
\text { rrikuntza Sozial Eral- } \\
\text { datzailearen arteko } \\
\text { dialektika zehaztu. } \\
\text { - sistema neoliberala- } \\
\text { ren dinamika baz- } \\
\text { tertzaileak eta atze- } \\
\text { rakoiak aurreikusi } \\
\text { horien kontra erreak- } \\
\text { zionatzeko. } \\
\text { gizartearen baloreak } \\
\text { sendotzen dituzten } \\
\text { ekimenak ezagutu. } \\
\text { aldaketa sozialerako } \\
\text { garrantzitsuak diren } \\
\text { mugimendu sozial } \\
\text { eta politikoak identi- } \\
\text { fikatu. } \\
\text { - prozesu eraldatzaileak } \\
\text { tokiko komunitatee- } \\
\text { tan eta enpresetan ga- } \\
\text { raile ateratzeko dina- } \\
\text { mika sozio-politikoak } \\
\text { eta instituzionalak } \\
\text { antzeman. } \\
\text { - Antolaketa herri eta au- } \\
\text { zoetan gauzatu, baita } \\
\text { ere herrialdean, nazioan } \\
\text { eta nazioartean: } \\
\text { - eraldaketaren aldeko } \\
\text { indar sozial, sindikal, } \\
\text { politiko eta institu- } \\
\text { zionalak bat egin. }\end{array}$ \\
\hline
\end{tabular}




\begin{tabular}{|c|c|c|}
\hline $\begin{array}{l}(1) \\
\text { Berrikuntzaren } \\
\text { izaera }\end{array}$ & $\begin{array}{c}(2) \\
\begin{array}{c}\text { Berrikuntzaren dimentsio } \\
\text { soziala }\end{array}\end{array}$ & $\begin{array}{l}\text { (3) } \\
\text { Berrikuntzaren } \\
\text { antolaketa }\end{array}$ \\
\hline $\begin{array}{l}\text { Balioen dimentsioari } \\
\text { garrantzia eman: } \\
\text { - baliodun pertsonak } \\
\text { ezinbestekoak dira al- } \\
\text { daketa burutzeko. } \\
\text { - korronte nagusiko } \\
\text { balio neoliberalei au- } \\
\text { rre egin (indibidua- } \\
\text { lismoa, kontsumis- } \\
\text { moa, lehiakortasuna, } \\
\text { demokrazia ordezka- } \\
\text { tzailea...). } \\
\text { balio alternatiboak } \\
\text { landu (balore kolekti- } \\
\text { boak, kontsumo arra- } \\
\text { zionala, lankidetza, } \\
\text { demokrazia parte- } \\
\text { hartzailea. } \\
\text {-Gatazkaren beharra al- } \\
\text { daketa eragiteko: } \\
\text { - gatazka ezinbestekoa } \\
\text { da urratsak emateko, } \\
\text { konponketak bila- } \\
\text { tzeko eta desoreka } \\
\text { sozio-ekonomikoak } \\
\text { gainditzeko. } \\
\text { gatazkak atentzioa } \\
\text { deitu eta inplikatu- } \\
\text { tako aktoreak irten- } \\
\text { bide zentzuzkoak eta } \\
\text { sortzaileak lortzera } \\
\text { behartzen du. } \\
\text { gatazka gizarte eral- } \\
\text { daketaren iturri da, } \\
\text { kapitalismoak eragin- } \\
\text { dako bidegabekeriak } \\
\text { salatzeko eta propo- } \\
\text { samen egingarriak in- } \\
\text { plementatzeko. }\end{array}$ & $\begin{array}{l}\text { - hiritar guztiei gizarte } \\
\text { zerbitzuak eta segur- } \\
\text { tasuna eskaini. } \\
\text { - hiritar ororentzat oi- } \\
\text { narrizko eskubide } \\
\text { sozialak bermatu. } \\
\text { - politika birbanatzai- } \\
\text { leak gauzatu. } \\
\text { - zerbitzu publiko } \\
\text { egokiak bermatu. } \\
\text { gizarte eta ekonomia } \\
\text { alorreko desberdin- } \\
\text { tasunak gainditu. } \\
\text { Merkatuaren paper po- } \\
\text { sitiboa bultzatu: } \\
\text { - } \text { merkatua eraginko- } \\
\text { rra denean. } \\
\text { merkatuak bat egi- } \\
\text { ten duenean gi- } \\
\text { zartearen interes } \\
\text { indibidual eta ko- } \\
\text { lektiboekin. } \\
\text { - enpresa-ahaleginak } \\
\text { eta ekimen priba- } \\
\text { tuak kolektiboaren } \\
\text { mesederako dire- } \\
\text { nean. } \\
\text { - Ekonomia Sozial Eral- } \\
\text { datzailearen ahalmen } \\
\text { guztia askatu: } \\
\text { - Ekonomia Sozial } \\
\text { Eraldatzailea Berri- } \\
\text { kuntza Sozial Eral- } \\
\text { datzailearen tresna } \\
\text { estrategikoa, harro- } \\
\text { bia eta sustatzailea } \\
\text { da. }\end{array}$ & $\begin{array}{l}\text { - elkarren arteko elka- } \\
\text { rrizketa, koordina- } \\
\text { keta eta lan amanko- } \\
\text { muna sustatu. } \\
\text { - } \text { aurrerapenak urratsez } \\
\text { urrats eman, epe mo- } \\
\text { tzeko pausoak epe er- } \\
\text { diko eta epe luzeko } \\
\text { pausoekin lotuz. } \\
\text { - } \text { tokian tokiko testuin- } \\
\text { gurua eta egin beha- } \\
\text { rreko bidea kontuan } \\
\text { hartu estrategia ego- } \\
\text { kia plazaratzeko. } \\
\text { - proposamen teo- } \\
\text { rikoak praktikare- } \\
\text { kin uztartu, egungo } \\
\text { errealitatetik abiatuz. } \\
\text { demokrazia parte- } \\
\text { hartzailea bultzatu. } \\
\text { - Prestakuntza ideologi- } \\
\text { koa sustatu: } \\
\text { - hiritarrak formatu } \\
\text { behar dira gizarte eta } \\
\text { ekonomia gaiak uler- } \\
\text { tzeko eta aztertzeko. } \\
\text { - } \text { segurtasuna lortu } \\
\text { talde dinamika ego- } \\
\text { kiak antolatzeko eta } \\
\text { herri eta auzoetako } \\
\text { arazoei heltzeko. } \\
\text { komunikazioa landu } \\
\text { antolatutako dina- } \\
\text { mika eraldatzaileak } \\
\text { gizarteratzeko. }\end{array}$ \\
\hline
\end{tabular}

Iturria: Geuk egina (2018). 
Berrikuntza Sozial Eraldatzaileak demokrazia parte-hartzailea ere sustatuko du. Hain zuzen ere herritarren parte hartzearekin hartuko dira erabaki sozial, politiko eta ekonomiko garrantzitsuenak. Informazioa lortzeko, eztabaida egokiak burutzeko eta erabakiak hartzeko Berrikuntza Sozial Eraldatzaileak parte hartzeko tresna egokiak antolatu beharko ditu.

Ilusioa sortu eta transmitituko duten pertsona militanteak animatzea eta antolatzea garrantzitsua da gustuko duten esparruetan lan egiteko. Horretarako zor zaion garrantzia emango zaio prestakuntza ideologikoari. Hiritarrak formatu behar dira gizarte eta ekonomia gaiak ulertzeko eta aztertzeko. Segurtasuna lortzea garrantzitsua da talde dinamika egokiak antolatzeko eta herri eta auzoetako arazoei heltzeko. Baita ere, komeni da ere komunikazioa lantzea antolatutako dinamikak gizarteratzeko.

Aldi berean, Berrikuntza Sozial Eraldatzailea gai izan behar da botere politiko subiranoa eratzeko oinarri oinarrizko eremuetatik hasita. Ahalik eta deszentralizazio administratiborik handiena bilatu beharko luke eta horretarako udal eta tokiko erakundeei eskumenak eta beharrezko baliabideak esleitzeko balio beharko du.

\section{Ondorioak}

Artikulu honetan Berrikuntza Sozial Eraldatzailearen funtzioa ondo finkatzeari lehentasuna eman zaio, ikuspegi sozio-politiko alternatiboak sortzeko eta eraldaketa sozialaren aldeko ahalmena garatzeko. Azken finean, gizartearen eraldaketara bideratutako Berrikuntza Sozialaren kontzeptuak, teoriak, praktikak eta estrategiak elkarlotu dira gaur egungo eredu neoliberalari aurre egiteko eta inongo bazterketarik gabeko mundu bat eraikitze bidean urrats sendoak emateko.

Bide horretan Berrikuntza Sozial Eraldatzaileak oinarri politiko eta ideologiko argiak eduki behar ditu bere potentzialitate guztia gizarte-eraldaketara bideratzeko. Hain zuzen ere, komeni da Berrikuntza Sozial Eraldatzailearen eginkizuna ondo kokatzea hausnarketa sozio-politiko alternatibo egokiak plazaratzeko eta praktikara eramateko. Zentzuzko alternatibak plazaratu dira. Horretarako sormena, antolaketa egokia, herritar desberdinen mobilizazio ahalmena eta instituzioei zuzendutako lankidetza eta interpelazioa erabili da. Garrantzitsua da jarduera horien arteko halako oreka bat bilatzea errendimendu sozial eta politikorik handiena gauzatzeko. Berrikuntza Sozial Eraldatzailearen helburua teoria politiko-ideologiko horiek martxan ipintzea izan da orain arte berrikuntzan eta arlo politikoan nagusi 
izan diren aurrerapen teknikoan eta irabazian oinarritutako diskurtsoetatik aldentzeko.

Azpimarratu daiteke baita ere Berrikuntza Sozial Eraldatzailean garrantzia alternatiben hedapenak eta sustapenak hartzen dutela. Behar handi bat dago praktika hoberenen forma aurrerakoiak hedatzeko eta iraunarazteko. Berrikuntza Sozial Eraldatzaileak benetako protagonismoa ematen dio eguneroko praktikan gauzatzen den eraldaketa sozialari. Hori dela eta, prozesu eraldatzailearen lehenbiziko helburua ekonomia eta gizarte eredu alternatiboa eraikitzea da. Komeni da elkarren arteko lankidetza azpimarratzea, proposamenak alderatzea eta lan egitea, erronka garrantzitsuei aurre egiteko, hala nola, herritarren gehiengoaren bizi kalitatea hobetzea, lana eta aberastasuna banatzea eta guztion helburuak batzen dituen ekimen sozio-ekonomikoa sakontzea. Eta teoria hutsean geratu gabe prestaturiko proposamenak praktikara eraman behar dira egungo errealitatetik abiatuz.

Argi eta garbi, krisiaren baldintzak bakarrik ez du bermatzen neoliberalismoaren kontrako ildoaren indarketa. Berrikuntza Sozial Eraldatzaileak esparru sozial alternatiboak sortu behar ditu balore indibidualista, kontsumista eta erreakzionarioekin funtzionatzen duten sare eta guneei aurre egiteko. Alternatiba aurrerakoiak garatzeko beharra, bideragarritasuna eta iraunkortasuna ez da nahikoa proiektu horiek gauzatzeko. Berrikuntza Sozial Eraldatzaileak ahalmena dauka neoliberalismoak azken hamarkadetan garatu duen ingurumen egituratu eta errotuan prozesu eraldatzaileak martxan ipintzeko. Hain zuzen ere, denbora horretan merkatuaren eta korporazioen aldeko arrazionaltasunak bat egin du egitura sozial, korporatibo eta finantzarioekin eta, aldi berean, estatu-boterearekin eta ez da erraza «humus» horretan kimu aurrerakoi berriak ernaltzea. Espazio ekonomiko, sozial eta politiko alternatibo horiek erreferentzia puntu garrantzitsuak bihur daitezke esperientzia positibo eta eraldatzaile horiek ezagunak egiteko eta gero beste espazio batzuetara garraiatzeko. Hau da, arnasgune horiek prozesu eraldatzailearen zabaltze estrategian paper garrantzitsua jokatzen dute.

Berrikuntza Sozial Eraldatzaileak bultzatu nahi duen prozesu eraldatzailea gaur egungo jokaleku neoliberaletik abiatzen da. Jokaleku neoliberal horretan, mugimenduan dagoen esparru bat izanik, aukera sortzaileak egon daitezke. Formulazio hori onartzen bada, neoliberalismoa ezaugarritu daiteke ez bakarrik muga garrantzitsuak dituen eredu bat bezala, baita ere aukera politikorako erregistro berrien jokaleku gisa. Horretarako egunez egun urratsak eman behar dira, norabide onean, iparra ondo finkatuz, epe motzeko urratsak epe erdiko eta luzeko urratsekin lotuz, garapen teorikoak errealitateko praktikarekin koordinatuz. Baino, beti ere, korronte neoliberalak asimilatu gabe. 


\section{Bibliografia}

Ayob, N., Teasdale, S., eta Fagan, K. (2016). How Social Innovation 'Came to Be': Tracing the Evolution of a Contested Concept. Journal of Social Policy, 45(4), 635-653.

Bouchard, M.J. (2006). De l'experimentation à l'institutionnalisation positive, l'innovation sociale dans le logement communautaire au Quebec. Annales de l'économie publique, sociale et cooperative, 77(2), 139-166.

Bouchard, M.J. (2007). L'innovation sociale en économie sociale. In J.-L. Klein eta D. Harrison (dir.), L'innovation sociale, émergence et effets sur la transformation des sociétés. Québec: Presses de l'Université du Québec.

Bouchard, M.J. (2013). The Social Economy in Québec: a Laboratory of Social Innovation. In M.J. Bouchard (Ed.), Innovation and the Social Economy (3-24 orr.). Toronto: University of Toronto Press.

Bovaird, T., eta Loeffler, E. (2012). From engagement to co-production: how service users and communities contribute to public services. In V. Pestoff, T. Brandsen and B. Verschuere (eds), New Public Governance, The third Sector and Coproduction (35-60 orr.). London: Routledge.

Brandsen, T., eta Pestoff, V. (2006). Co-production, the third sector and the delivery of public services. Public Management Review, 8(4), 493-501.

Brundtland, G.H. (1987). Nuestro futuro común. Informe de la Comisión Mundial sobre el Medio Ambiente y el Desarrollo. New York: Asamblea General de la ONU.

Chambon, J.-L., David, A., eta Devevey, J.M. (1982). Les innovations sociales. Paris: Presses Universitaires de France.

Drucker, P. (1987). Social Innovation: management's new dimension. Long Range Planning, 20(6), 29-34.

Duñaiturria, S. (2007). Influencia de la Filosofía contemporánea en el progreso de la humanidad: alternativa al neoliberalismo. Bilbo: Erroteta.

Hillenkamp, I. (2016). ¿Innovar para sostenerse? Representaciones y prácticas de Economia Popular Solidaria en América Latina. In C. Puig, Economía Social y Solidaria: conceptos, prácticas y políticas públicas (65-82 orr.). Bilbao: UPV/ EHU, Hegoa.

Hoggan, F. (1909). The American negro and race blending. The Sociological Review, 2(4), 349-360.

Klein, J.L. (2013) Introduction: social innovation at the crossroads between science, economy and society. In F. Moulaert, D. MacCallum, A. Mehmood eta A. Hamdouch, The International Handbook on Social Innovation (9-12 orr.). Cheltenham, UK: Edward Elgard Publishing Limited.

Klein, J.-L., eta Harrison, D. (2010). L'innovation sociale. Émergence et effets sur la transformation des sociétés. Québec: Presses de l'Université du Québec.

Lévesque, B. (2006). Le potentiel d'innovation et de transformation de l'economie sociale : quelques éléments de problematique. Economie et Solidarités, 37(2), $13-48$. 
Lévesque, B. (2011) Un monde qui se défait, un monde à reconstruire. L'Action nationale, $133,157-184$.

Mendizabal, A. (2012). Aproximación a la autogestión en la economía de mercado. Saarbrücken: Editorial Académica Española.

Moulaert, F., MacCallum, D., eta Hillier, J. (2013). Social innovation: intuition, precept, concept, theory and practice. In F. Moulaert, D. MacCallum, A. Mehmood eta A. Hamdouch, The International Handbook on Social Innovation (13-24 orr.). Cheltenham, UK: Edward Elgard Publishing Limited.

Moulaert, F., MacCallum, D., Mehmood, A. eta Hamdouch, A. (eds.). (2013). The International Handbook on Social Innovation. Cheltenham, UK: Edward Elgard Publishing Limited.

Novy, A. (2017). Transformative Social Innovation. SRE-Discussion Papers, 2017/05. Vienna: WU Vienna University of Economics and Business.

Peck, j. (2013). Social Innovation... at the limits of neoliberalism. In J.L. Klein eta M. Roy (dir.), Pour une nouvelle mondialisation, le défi d'innover (11-29 orr.). Québec : Presses de l'Université du Québec.

Pol, E. eta Ville, S. (2009). Social Innovation: Buzz word or enduring term? The Journal of Socio-Economics, 38(6), 878-885.

Richez-Battesti, N., Petrella, F., eta Vallade, D. (2012). L'Innovation sociale, une notion aux usages pluriels: Quels enjeux et défis pour l'analyse? Innovations, 38, 15-36.

Tarde, G. (1899). Social laws: an outline of sociology. New York: Macmillan.

TRANSIT (2018). Transformative Social Innovation theory. The TRANSIT Project. http:/www.transitsocialinnovation.eu/, 2018ko ekainaren 23an begiratua.

Unger, R.M. (2015). Conclusion: the Task of the Social Innovation Movement. In A. Nicolls, J. Simon, eta M. Gabriel (eds.), New Frontiers in Social Innovation Research (233-251 orr.). Hampshire: Palgrave Macmillan. 